IFN Working Paper No. 851, 2010

\title{
The Real Effects of Private Equity Buyouts
}

Joacim Tåg 


\title{
The Real Effects of Private Equity Buyouts*
}

\author{
Joacim Tåg \\ Research Institute of Industrial Economics (IFN)
}

September 8, 2010

\begin{abstract}
Private equity buyouts have become a common element in the industrial development process. I survey the literature on the real economic effect of buyouts: employment, wages, productivity, and long-run investments. Employment tend to marginally fall after a buyout in most countries studied, with the exception being France. There are clear evidence of productivity gains following a buyout, with part of these being shared with worker through higher wages. The evidence is mixed regarding effects on long-run investments.
\end{abstract}

Keywords: Leveraged Buyouts, Private equity buyouts, Real effects, Employment, Productivity, Innovation, Long-run investments.

JEL Codes: G20, G30, G34, J2, L2

\footnotetext{
*The author gratefully acknowledges financial support from the NASDAQ OMX Nordic Foundation and Tom Hedelius' and Jan Wallander's Research Foundations. This paper was written within the Gustaf Douglas Research Program on Entrepreneurship at the Research Institute of Industrial Economics (IFN). The author thanks Douglas Cumming, Martin Olsson, Lars Persson and Konrad Raff for constructive comments on early drafts, and Aron Berg for excellent research assistance. This survey was prepared for the Oxford University Press Handbook on Private Equity.
} 


\section{Introduction}

Private equity buyouts are acquisitions of established companies undertaken by private equity firms. They are partly financed with debt and partly with equity raised from institutional investors for private equity funds with a predetermined life span. Private equity buyouts are also known as leveraged buyouts or bootstrap acquisitions. When management participates, they are sometimes called management buyouts.

The private equity industry took off during the 1980s. As a large wave of takeovers swept across the U.S., buyouts became a new phenomenon that was much talked about and scrutinized. When the takeover wave receded at the end of the 1980s, so did the number of buyouts. But as illustrated in Figure 1, it only took three years for buyouts to make their comeback and break new records by spreading out from the U.S. During 2000 to 2007, a worldwide explosion in the number of buyouts occurred and a staggering 79\% of all buyouts between 1970 and 2009 took place after 1999. In particular, there has been an increase in the number of buyouts outside the U.S. and the U.K. As illustrated by Figure 2, at the peak of the boom in the 1980s, 93\% of all buyouts took place in the U.S. or the U.K. At the peak of the boom in the $2000 \mathrm{~s}, 53 \%$ of all transactions took place in the U.S. or the U.K.

The spread of the buyout phenomenon has not escaped criticism (FSA, 2006; ITUC, 2007; PSE, 2007). Labor unions and worker representatives claim that buyouts, through layoffs and wage cuts, generate returns to investors at the expense of workers. Industry critics express some concern about the detrimental effects of short holding periods by citing examples of "quick flips", in which companies are sold off within two years after the buyout.

This has prompted the view that private equity firms are short-term investors that are always on the lookout for a quick exit at the expense of employees, productivity and long-run investments. The private equity industry has not sat idle. Responding with studies of its own, its interest organizations have refuted the accusations and claimed that buyouts create better companies, increase job creation and promote long-term productivity (Achleitner and Klöckner, 2005; BVCA, 2006).

But why should a buyout affect employment, productivity and long-run investments? And what are the empirically documented effects? This overview offers an answer by drawing on a literature in economics and finance stretching back to the 1980s when the industry first emerged. Throughout, the emphasis will be on real effects, omitting such aspects as the effect of a buyout on operating profitability, returns to investors and tax payments. Studies that cannot separate between the effects of venture capital and private equity investments will also be omitted. For complementary overviews of the literature on buyouts covering these aspects, see e.g. Cumming et al. (2007), Kaplan and Strömberg (2009) or Wright et al. (2009).

The real effects are important since a buyout has the potential of affecting static efficiency (e.g. productivity), dynamic efficiency (e.g. innovation) and imposing (positive or negative) externalities on stakeholders in the firm (e.g. the employees). Empirical and theoretical studies 


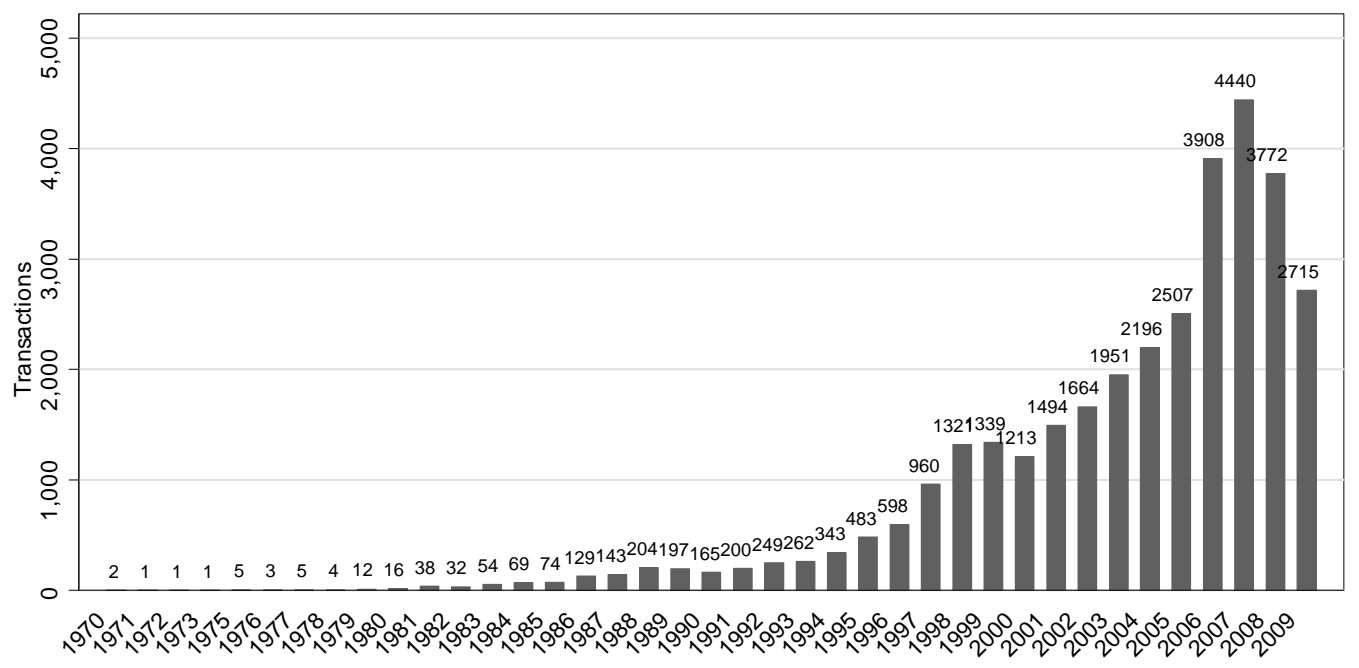

Figure 1: Number of closed or effective transactions worldwide from 1.1.1970-31.12.2009 in the Capital IQ database that are marked as LBO or MBO. For a careful discussion on the coverage of the Capital IQ database, see Strömberg (2008).

on employment, wages, productivity, innovation and bankruptcy provide us with hints on what the social welfare implications of an active private equity market are likely to be.

In sum, the literature has discussed several reasons why a private equity buyout could have real effects. They can be grouped into three categories: a buyout reduces agency problems, it introduces uncertainty and temporary owners, and brings in capital and knowledge to the organization. These changes affect employees, productivity and long-run investments.

Reducing agency problems realigns the incentives between managers and owners and can lead to reductions in employment and increases in productivity as the effects of empire building become undone. The same effects can be expected from increased uncertainty and new owners as it becomes easier to breach implicit contracts and implement changes in the organization. Temporary ownership can increase incentives to improve productivity as private equity backed firms maximize an exit valuation and thus take actions to increase the bidding competition in case of a trade sale. But temporary ownership could also lead to a short-term focus negatively affecting long-run investment. Finally, additional capital and better knowledge of management practices are of importance. A capital injection can spur the growth of the firm (or a division of a firm taken private) leading to increases in employment and new investments, and an improved knowledge of operational management practices could lead to increases in productivity.

In broad terms, the empirical evidence is consistent with these predictions. Employment tend to marginally fall after a buyout in most countries studied, with the exception being France. There are clear evidence of productivity gains following a buyout, with part of these being shared with worker through higher wages. The evidence is mixed regarding effects on long-run investments. In general, the evidence is consistent with buyouts leading to a reallocation of resources to more productive uses. As expressed by Davis et al. (2008): private equity firms 


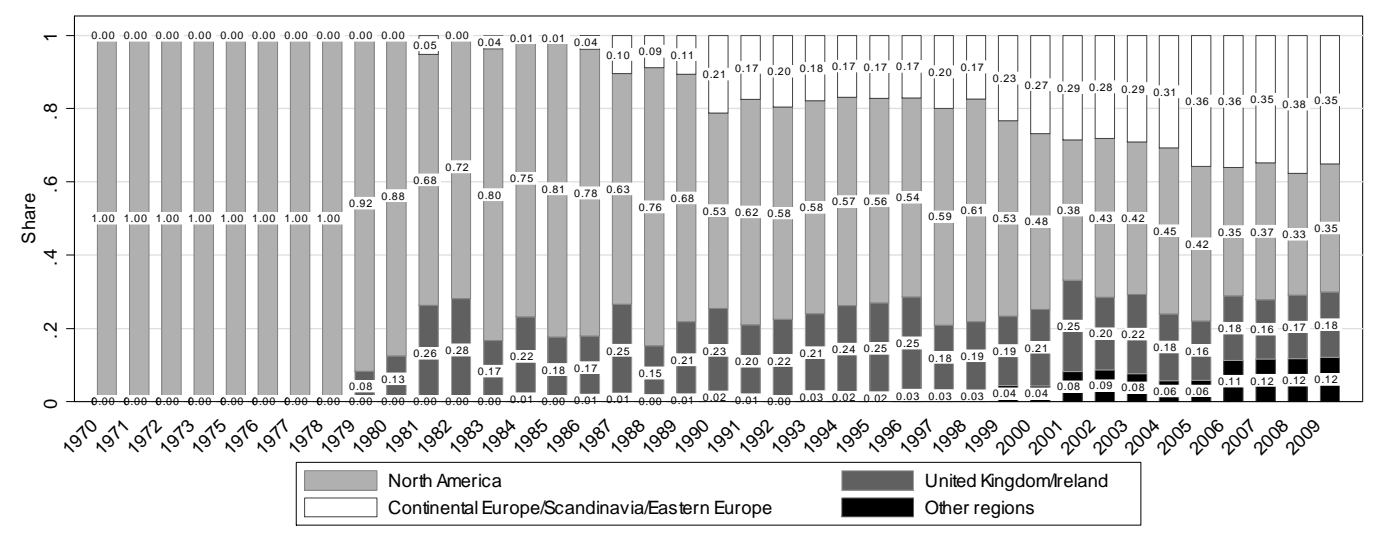

Figure 2: Geographical breakdown of the number of closed or effective transactions worldwide from 1.1.1970-31.12.2009 in the Capital IQ database that are marked as LBO or MBO. For a careful discussion on the coverage of the Capital IQ database, see Strömberg (2008).

are catalysts of creative destruction.

Despite a growing literature on the real effects of buyouts, more research remains to be done. So far, there is no formal theoretical foundation for the real effects of buyouts, and more work is needed on determining the sources of static and dynamic efficiency changes postbuyout. Future researchers should also delve further into disentangling the effect of private equity ownership from the effect of ownership change, and figure out if the real effects have changed over time or if they differ between the types of buyouts undertaken. Finally, as most empirical evidence is from the U.S. or the U.K., we have little knowledge of how the real effects vary across countries and if they do, why this is the case.

The roadmap reads as follows. Section 2 discusses why a buyout could have real economic effects. Section 3 then surveys the empirical literature on the relation among buyouts and employment, productivity, long-run investments and bankruptcy. Section 4 discusses further research and concluding remarks are made in Section 5.

\section{Why Could a Buyout have Real Effects?}

While few formal analyses exist, and only some authors explicitly discuss real effects, the literature on private equity buyouts provides a good basis for a discussion on the real effects of buyouts. The ways in which a buyout could have real effects can be grouped into three categories: a buyout reduces agency problems; it introduces uncertainty and temporary owners; and it brings in new capital and better knowledge of management practices. 


\subsection{A buyout reduces agency problems}

In foundational papers on the role of buyouts, Jensen $(1986,1989)$ argued that private equity firms - or leveraged buyout associations - are an organizational form superior to the public corporation as it is designed to reduce agency problems between dispersed owners and the manager of the firm (Berle and Means, 1932: Jensen and Meckling 1976). Dispersed ownership allows managers to avoid hard and unpopular tasks such as firing employees, reducing wages and negotiating lower prices with suppliers. Without careful monitoring and the right incentives, managers can engage in empire building by hiring too many employees, acquiring too many companies, or diversifying activities too much (Jensen 1986, Williamson 1964). Jensen $(1986,1989)$ argued that a buyout could reduce these problems since private equity firms concentrate ownership, implement a close connection between pay and performance, and increase leverage.

Concentrating ownership is central, since dispersed ownership in a public corporation is accompanied with low incentives to monitor the manager. Monitoring the manager is a public good and shareholders have incentives to free-ride on each other (Berle and Means 1932; Williamson 1964; Shleifer and Vishny, 1986). A buyout concentrates ownership and thereby removes the free-riding problem. Once the free-riding problem is gone, problems with low performance and empire building can be dealt with by implementing compensation contracts tying performance to pay, and by increasing leverage.

Compensation contracts tying performance to pay align the interests of owners and the manager and could thereby lead to improvements in productivity (Jensen and Meckling, 1976; Holmström, 1979; Jensen and Murphy, 1990). Alignment can also be achieved by the manager receiving ownership in the firms or by him or her being required to invest in the firm. Increased managerial ownership also has other benefits. Under asymmetric information, it can lead managers to reveal information to the owners they would otherwise not have disclosed (Opler and Titman, 1993; Lazear, 2005). Moreover, if the manager is required to take a large stake in the company and refuses, he/she might not have disclosed all relevant information.

Increased leverage can help reduce agency problems as, apart from financing the transaction, it forces the manager to pay out "free cash flows" (Murphy, 1985; Jensen, 1986). Free cash flow is money left in the firm after all projects with a positive net present value have been funded. Increasing leverage is a way of forcing the manager to return free cash flow to the owners instead of investing the funds in projects with a negative net present value. Increased debt also makes the probability of default and managerial turnover larger and therefore leads to increased efforts by the manager (Grossman and Hart, 1982; Zwiebel, 1996). Moreover, when combined with ownership in the firm, debt increases the pay sensitivity of the manager, making him or her more likely to operate in the interests of the owners.

The changes in ownership concentration, managerial ownership and leverage are likely to have real effects. If dispersed ownership, a weak connection between pay and performance, and 
too low leverage allowed the previous management to hire too many employees and diversify operations too much, a buyout can have real effects by reversing the damage done and thereby leading to a decrease in employment and an increase in productivity.

The increase in leverage could also have a negative impact on long-run investment and employee wages. There exists evidence of a negative correlation between R\&D spending and leverage (Himmelberg and Petersen, 1994) and increased leverage gives more bargaining power to the firm in wage negotiations (the firm can credibly threaten not to undertake new investments unless wages are reduced as argued by Perotti and Spier (1993)). In addition, too much debt can lead to debt overhang resulting in reduced investment incentives (Myers, 1977). Finally, increased leverage could lead to an increased risk of bankruptcy and, in the extreme, a full shutdown of operations.

\subsection{A buyout introduces uncertainty and new temporary owners}

Besides reducing agency problems, a buyout introduces uncertainty and temporary owners. Schaefer (1998) argues that it can be easier to change compensation structures and improve productivity by moving people to new positions within the organization when employees feel less secure in their jobs.

The ownership change itself may also be important. Shleifer and Summers (1988) argue that an ownership change makes it easier to breach implicit contracts with workers, suppliers and other stakeholders. An entrenched manager facing a difficult situation could also have a harder time letting employees go, or shifting resources to more productive uses, than if this manager were to be replaced by a new manager as a result of the ownership change. Replacing the manager is easier if an ownership change takes place. As argued by Cuny and Talmor (2007), new owners have the advantage of not having a tight relationship with the manager which allows them to consider all turnaround possibilities, even those that involve replacing the manager.

The new owners are also temporary owners. The median holding period of a company is 6 years according to Kaplan and Strömberg (2009). As temporary owners, they could face different incentives to undertake long-run investments and restructuring activities as compared to more permanent owners.

A reduction in long-term investments could be a concern in "quick flips" (deals in which the holding period is shorter than two years). These deals are profitable. Using a dataset of around 7500 investments of 250 private equity firms worldwide from 1971 to 2005, Lopez-deSilanes et al. (2009) show that short holding periods (less than two years) generated an average IRR (internal rate of return) of $79 \%$, in comparison to an IRR of $10 \%$ for investments held longer than four years. Incentives to perform "quick flips" thus exist, and it is easy to imagine that long-run investments could be sacrificed for more short-term gains. An argument against this, however, is that the eventual buyer will care about the long-run value of the firm and thus 
temporary owners should have no incentives to sacrifice long-run investments for short-run gains as this would depress the exit valuation of the target firm.

Temporary ownership can also lead to increased incentives to improve productivity. Norbäck et al. (2010) argue that if buyouts take place in concentrated industries and are exited through trade sales, private equity firms maximizing trade sale revenues have stronger incentives than more permanent owners to ensure the management team works hard at restructuring the firm. The intuition is that the possible buyers are willing to pay for both the restructured assets and to prevent a rival from obtaining them. The more productive the assets are, the more valuable it is for bidders both to obtain the assets and prevent a rival from obtaining them. Since permanent owners do not maximize trade sale revenues, temporary ownership should lead to relative increases in productivity.

\subsection{A buyout brings in capital and knowledge}

Additional capital and improved knowledge of management practices have the potential of leading to increases in employment, productivity and long-run investments. Boucly et al. (2009) argue that in some environments, buyouts can be a good substitute for other sources of capital and thereby increase employment growth. The authors support their argument using French data for 830 buyouts in France during 1994-2004 by showing that the strongest employment growth is observed in industries where external financing is often needed for the industries to grow.

A buyout can also be a way for a capital-constrained division manager to secure financing for taking the division private (if the company is interested in selling it). This motivation for buyouts have been discussed in the management literature (Fox and Marcus, 1992; Zahra, 1995; Wright et al., 2000, 2001). The main argument is that buyouts help entrepreneurial managers escape the bureaucracy of large corporations. Empirical support for this argument is given in Fidrmuc et al. (2008). They study a sample of 221 U.K. public-to private transactions completed between 1997 and 2003. They show that management buyouts take place without the help of private equity firms if management can itself reap the benefits of the deal, but that management brings in private equity firms when the firm has less cash, the manager holds a smaller equity share and the firm is large; exactly when additional external capital is needed.

Alleviating credit constrained managers in divisional (management) buyouts can have a positive effect on long-run investments. For example, Gertner et al. (1994) argue that internal financing of a project can reduce innovation incentives because the firm controls the project and can extract rents from a manager ex post. External financing then improves the innovation incentives. Gromb and Scharfstein (2002) argue that internal development of a project can come with costs, as a manager in charge of the project can be redeployed inside the firm if the project fails. This reduces the incentives to work hard on the innovation. Outside development, on the other hand, makes the manager work harder as he or she is forced to find a new job if 
the project fails. Hellmann (2007) also presents a multi-task model arguing that in equilibrium, employees sometimes leave the firm and develop an innovation externally because the firm wants the employee to focus on its core tasks instead of spending time on developing new innovations.

Private equity firms also bring with them knowledge about management practices. This could lead to improvements in productivity. Using data on management practices in around 4,000 medium sized manufacturing firms world-wide, Bloom et al. (2009) show that private equity backed firms are, on average, better managed than privately owned firms, family firms or government-owned firms. The reason is a lack of a "tail" of badly managed firms; almost all private equity backed firms have good management practices. They also show that private equity backed firms tend to be particularly good at operational management practices, suggesting that a buyout could have a positive influence on productivity by bringing in good knowledge of management practices.

In sum, there are multiple reasons why a buyout could have real effects. While the effects on employment and long-run investments could go either way, most arguments favor increases in productivity.

\section{What are the Empirically Documented Effects?}

Empirical studies on the real effects have found evidence consistent with the above discussion. Most empirical studies, but not all, have found that a buyout is correlated with increases in productivity, weakly negative or no effects on employment, weak increases in wages, and small or no effects on long-run investments. There are no effects on the bankruptcy rate, although it varies over time and across countries. This evidence is summarized in Table 1 available in the Appendix.

\subsection{Employment and wages}

Perhaps the most controversial issue regarding buyouts is the effect of a buyout on employees. While labor unions are often quick to point out examples of large layoffs following a buyout, private equity associations often underscore that targets tend to grow in size after the buyout. Empirical studies on the employment effects of buyouts have, on average, found no or weakly negative effects on employment and slight positive effects on wages. The exception is France, where buyouts have a strong positive effect on employment.

Evidence from the U.S. suggests that employment effects are weakly negative. Kaplan (1989) studies a sample of 48 large management buyouts that took place between 1980 and 1986 and finds that median employment increased by $0.9 \%$ if divestures are counted as job losses. In relation to the industry median, however, firms subject to a buyout have a $12 \%$ lower job growth. Not counting firms that divest more than $10 \%$ of the buyout value - leaving a 
sample of 26 firms - the median job growth is $6.2 \%$ slower than the industry median. This is similar to Muscarella and Vetsuypens (1990) who study a sample of 72 U.S. firms that underwent a leveraged buyout and subsequently went public again between 1976 and 1987. They find a decline in employment of $0.6 \%$ between the time the buyout took place and when the firm went public. This is lower than for the comparison group, and it can be attributed to divestures; they find an increase in median employment by $17 \%$ for the 12 firms that did not do divestures. Leveraged buyouts between 1986 and 1989 could have had less of an effect on employment. Opler (1992) studies 44 public to private leveraged buyouts and finds no significant employment effects of the buyout.

A drawback of using firm level data is the difficulty in separating out employment effects arising from organic growth from those arising from acquisitions and divestitures. Plant level studies can separate between these effects.

Lichtenberg and Siegel (1990) gather plant level data on 1108 plants that underwent a leveraged buyout or a management buyout between 1983 and 1986. Their total sample, including the comparison group, is on around 12,000 manufacturing plants observed between 1972 and 1986. They find a cumulative decline in white collar employment of $8.5 \%$ over three years (one year pre and two years post buyout). However, blue collar employment declines are not statistically significant. Hence, the main employment effect is on white-collar workers: the ratio of white-collar to blue-collar workers declines by $6.5 \%$ relative to the industry average. In addition, they find a cumulative three-year (one year pre- and two years post-buyout) relative increase in blue-collar wages of $3.6 \%$ for annual wages and $2.3 \%$ for hourly wages. This indicates that job creation and job losses do not occur with the same intensity up and down the corporate hierarchy. White-collar workers draw the shortest straw.

Using more recent and comprehensive plant level data, Davis et al. (2008) collect a dataset of around 300,000 U.S. establishments operated by about 4,500 firms subject to a leveraged buyout between 1980 and 2005. Comparing with a control group at the establishment level matched on industry, age and size, they find an average cumulative two-year relative employment decline of $7 \%$ at target establishments remaining with the firm. They also find slower employment growth at target establishments before as well as after the buyout, suggesting that buyouts of quickly growing firms are not common. Gross job creation is similar between the comparison group and targets, so it is likely that job destruction at target establishments is driving the results. But the decrease in employment at remaining establishments is partly offset by the creation of new establishments. For a smaller sample of around 1,300 transactions, they show that target firms tend to create more new establishments. This leads to a two-year cumulative relative $6 \%$ increase in job creation. Continuing their work using a dataset on 1,400 manufacturing firms subject to a leveraged buyout between 1980 and 2005, Davis et al. (2009) show that continuing establishments at targets pay workers a wage that is $1.1 \%$ higher than continuing establishments in the comparison group around the time of the transaction. However, this difference disappears two years after the transaction. Thus, U.S. evidence suggests 
negative effects on employment, but positive wage effects for employees remaining with the target.

Evidence from U.K. buyouts is similar, although somewhat weaker. Wright et al. (1992) study a survey sample of 182 leveraged buyouts at the firm level for 1983-1986 and conclude that post-buyout, an initial decline in employment of around $6.3 \%$ occurs. It recovers over time to $4.5 \%$ below the pre-buyout level. Amess and Wright (2007) study a sample of 1,350 management buyouts and management buy-ins observed at the firm level between 1999 and 2004. They find no correlation with changes in employment or wages, but they do find a slight decrease in wages relative to the comparison group. They also find heterogeneity in the employment effects between buy-ins and buyouts. Management buy-ins tended to have a relatively lower employment and wage growth than management buyouts.

No aggregate effects on employment are in line with Amess et al. (2008) who show, using a sample of 232 leveraged buyouts observed between 1996 and 2006, that private equity backed buyouts have no effect on employment or wage growth relative to the comparison group. However, Cressy et al. (2007) study a sample of 57 buyouts matched with 83 comparison firms for 1995-2002 and find that over the first post-buyout year, employment falls by $7 \%$ relative to the comparison group. This grows to $23 \%$ below that of the comparison group over the first four years. In year five, employment increases relative to the comparison group. This is similar to evidence from Weir et al. (2008) who studied 122 public to private buyouts between 1998 and 2004 and found job losses for the first two years after going private, but subsequent increases in years four and five as compared to firms remaining public.

Evidence on employment effects beyond the U.S. and the U.K. is scarce. Buyouts in Sweden have no effect on employment and wages, at least according to Bergström et al. (2007) who use a sample of 69 buyouts between 1993 and 2005. The evidence from France is drastically different. Boucly et al. (2009) study 830 buyouts in France that took place between 1994 and 2004. Compared to the comparison group, they find a remarkable employment growth of $13 \%$ in the period three years before the transaction to four years after. They argue that most of the gains come from organic growth. This finding is in sharp contrast to studies from the U.S. and the U.K. The authors argue that buyouts in France work as a substitute for weak capital markets and thereby help finance firm growth. At a more aggregate level, Bernstein et al. (2010) study the effect of private equity on industry performance worldwide. Using a sample of about 14,300 leveraged buyout transactions and industry data across all OECD countries, they find that from 1991 to 2007, industries that have received private equity investment in the last five years have grown more quickly than other industries in terms of employment, total production and value added.

Besides the employment and wage effects of a buyout, survey evidence exists on how a buyout affects worker discretion, involvement and training. Amess et al. (2007) study a sample of 1,959 firms and 27,263 employees from the UK Workplace Employee Relations Survey and find that companies subject to a management buyout give craft and skilled service employees 
more discretion. These workers also tended to be less supervised. This suggests that management buyouts reduce hierarchical tiers and layers of middle management, consistent with the evidence from Lichtenberg and Siegel (1990) mainly showing employment declines for whitecollar workers. Further, Bruining et al. (2005) study a survey sample of 145 buyouts in the U.K. and 45 in the Netherlands and find a positive effect on employer training and employee involvement (with the effects being stronger in the U.K. than in the Netherlands).

\subsection{Productivity}

Empirical evidence suggests that a buyout is correlated with enhanced productivity partly arising from a reorganization of operations: private equity firms tend to close low productivity establishments and open new more productive ones. Outsourcing of intermediate goods also allows a reduction in labor intensity, thus contributing to productivity growth.

Using U.S. data, Lichtenberg and Siegel (1990) study total factor productivity at the plant level. They find that plants involved in leveraged or management buyouts experience a substantial increase in productivity as compared to control plants not going through a buyout. The median productivity difference one to three years after the buyout is $5.9 \%$. Further, plants selected for a buyout are more productive than comparable plants even before the buyout: the median productivity difference one to three years before the buyout is $2.3 \%$. The gains in productivity are not related to reductions in wages, $R \& D$ or capital expenditures. This evidence is consistent with Davis et al.'s (2009) study of a dataset of 1,400 manufacturing firms operating 14,000 establishments subject to a buyout between 1980 and 2005. They find 2\% greater productivity growth at targets in relation to the comparison group within two years following the buyout. Labor productivity was, on average, about 5.2\% higher. Productivity growth is divided such that two thirds are due to productivity improvements at continuing establishments while one third comes from productivity contributions from new establishments. Net entry of establishments happens because targets, in relation to the comparison group, are more likely to close underperforming establishments and open new ones. Davis et al. (2009) estimate that private equity transactions in their sample resulted in an additional real output of up to $\$ 15$ billion in 2007 - an economically significant effect.

Evidence from the U.K. is also available. Amess (2002) studies a firm-level sample of 78 U.K. management buyouts taking place over the period 1986 to 1997. Compared to a control sample of 156 firms matched on input characteristics, he finds that management buyouts tended to increase relative productivity in the manufacturing of machinery and equipment industry, leading to a $16.13 \%$ increase in output. In line with this, Amess (2003) finds, using a similar dataset, that the technical efficiency of firms that underwent a management buyout has a higher efficiency two years before the transaction and higher efficiency levels of $7 \%$, $7.5 \%, 4 \%$ and $7 \%$ in the four years following the buyout. Harris et al. (2005) gather data for 979 management buyouts and 4,877 manufacturing establishments in the U.K. that underwent 
a management buyout during 1994 to 1998 and show that total factor productivity increases substantially (70.5-90.3\%) relative to the comparison group (their total sample covers 35,752 establishments). The authors argue that the productivity increase is due to a reduction in labor intensity of production made possible through outsourcing of intermediate goods and materials. They also find that pre-buyout total factor productivity at targets is $1.6-2.0 \%$ lower in relation to the comparison group, thus suggesting that less productive establishments are targeted for buyouts. However, this is in contrast to Lichtenberg and Siegel (1990) and Amess (2003) who find that more productive establishments are targeted for buyouts.

\subsection{Long-run investments}

The impact of a buyout on long-run investments has been studied by focusing on expenditures on $R \& D$ and patenting intensity. The empirical evidence is mixed. Studies on $R \& D$ expenditures have found both positive and negative changes following a buyout, while studies on patenting intensity show a concentration in patenting activity towards more economically significant patents and towards the firm's historical focus.

Using U.S. data, Lichtenberg and Siegel (1990) find that target plants are less R\&D intensive than non-target plants (2.5\% lower in mean one to three years before the buyout) and that targets tend to be concentrated in less $R \& D$ intense industries. However, relative to the comparison group they find no significant difference in R\&D spending. This is consistent with Hall (1990) who studies a sample of around 80 leveraged buyouts between 1977 and 1988 and finds that buyouts tended to take place in industries with little R\&D. She finds no large effects on $\mathrm{R} \& \mathrm{D}$ spending of an LBO, but reductions as a result of corporate acquisitions with high leverage. Smith (1990) studies the post-buyout performance of around 58 management buyouts between 1977 and 1986 and Opler (1992) studies 44 public to private leveraged buyouts between 1985 and 1989. Neither does Smith (1990) or Opler (1992) find any negative effects of an LBO on R\&D spending. Zahra (1995), who studies a survey sample of 47 management buyouts, does not find any effect on R\&D spending. He does, however, find some evidence that there is an increase in product development, technology related alliances, and new business creation activities. This is similar to Wright et al. (1992) who show that a full $62 \%$ of surveyed firms subject to a buyout in the U.K. reported that the buyout allowed them to develop new products they would otherwise not have developed. A negative effect on R\&D expenditures is found in Long and Ravenscraft (1993) who also find that leveraged buyouts tended to take place in less R\&D intense companies (roughly 50\% less than the mean in manufacturing). Their sample consists of 72 leveraged buyouts with R\&D spending and 126 leveraged buyouts without any R\&D spending between 1981 and 1987 (they use a control group of 3,329 firms). The drop in $R \& D$ expenditures post buyout is around $40 \%$, but companies reducing $R \& D$ spending tended to do worse than the firms that did not.

Another measure of long-run investments is patents; evidence suggests that a buyout leads 
to a concentration in patenting efforts and an increase in the economic significance of patents applied for. Lerner et al. (2008) study 495 U.S. leveraged buyouts undertaken between 1983 and 2005 and link them to patents and patent citations from the US Patent and Trademark Office. They find that post-buyout, more "important" innovations are patented, with "importance" measured by patent citations, and the patent portfolio becomes more focused: patents tend to concentrate in to patent classes where the target has had its historical focus. However, there are no effects on patent originality, generality or quantity.

Using a cross-country sample, Ughetto (2010) studies the patenting activity of a sample of 681 Western European manufacturing firms subject to a buyout between 1998 and 2004. She finds that the average number of patents increases by around 50\% after as compared to before the buyout. The characteristics of the leveraged buyout affect patenting intensity. In particular, syndicated buyouts, buyouts with a buyout-specialized lead investor, or buyouts with a lead investor with a large portfolio tend to be buyouts where patenting activity increased the most. Geographical proximity and location do not correlate with patenting intensity.

\subsection{Bankruptcy}

One channel through which a buyout could have real effects is by increasing the risk of bankruptcy (due to increased leverage) and thus, in the extreme, it could lead to a full shutdown of operations. However, no studies have found a clear connection between a buyout and an increase in the probability of a bankruptcy, although there is evidence that the bankruptcy rate varies over time and across countries.

Kaplan and Strömberg (2009) examine a sample of 17,171 buyouts undertaken worldwide between 1970 and 2007 and find that 6\% of all deals have ended in bankruptcy or reorganization. With an average holding period of six years, it is consistent with an annual bankruptcy rate of $1.2 \%$; lower than the average default rate of $1.6 \%$ for U.S. corporate bond issuers between 1980 and 2002. However, it is higher than the $0.6 \%$ bankruptcy rate for U.S. publicly traded firms (Wright et al. 2009). Boucly et al.'s (2009) study of 830 buyouts in France during 19942004 find no increase in bankruptcy rates after a buyout as compared to their control group. At some point, $6.1 \%$ of the targets and firms in the comparison group will go bankrupt. Within three years after the buyout, $3.5 \%$ of both targets and firms in the comparison group ended up in bankruptcy.

Yet, the bankruptcy rate varies with the business cycle and across countries. Kaplan and Stein (1993) study a sample of 41 U.S. management buyouts that took place between 1980 and 1984. Only one of the deals (2\%) defaulted. But of the 83 management buyouts in their sample between 1985 and 1989, a full $27 \%$ defaulted and a total of almost $11 \%$ ended up in bankruptcy.

Lopez-de-Silanes et al. (2009) document that around 10\% of all deals (world-wide) in their sample ended in bankruptcy, with the bankruptcy rate varying from 5\% in Scandinavia, to $8 \%$ 
in France, $10 \%$ in the U.K, $12 \%$ in the U.S and a full $13 \%$ in Germany. A caveat, however, is that they define bankruptcy as either reported bankruptcy in the Private Placement Memoranda or as a deal not giving returns to capital (which could be for other reasons than a bankruptcy).

Even if a default on debt occurs, it may not have any real effects. Andrade and Kaplan (1998) study 31 of the management buyouts in Kaplan and Stein (1993) that later became financially distressed (due to high leverage). They find that firms in their sample had a slight positive increase in value before they became financially distressed, suggesting that, on average, the value of the firm does not actually decline.

\section{Where we Stand}

Empirical studies have found that employment reductions tend to occur in the U.S. and also to some extent in the U.K., but that that buyouts in France contribute to job growth. Wages tend to increase slightly for blue-collar workers and for workers at establishments that remain with the firm. The empirical studies have also found that a buyout seems to have positive effects on productivity, with evidence suggesting that it arises from increased labor productivity and from closing down unproductive establishments and opening more productive ones. Outsourcing of intermediate materials and goods also provides contributions. Further, the empirical studies have found that the effect of a buyout on long-run investments is mixed. We have indications that buyouts tend to take place in less $R \& D$ intense industries, but evidence is mixed on whether R\&D spending increases or decreases. Patenting activity post-buyout seems to concentrate on more economically meaningful patents and patenting activity seems to depend on characteristics of the deal and who is the lead investor.

But much more work remains to be done. In particular, the following dimensions are fruitful avenues for further research.

First, formal economic theory on the real effects of buyouts is almost non-existent, even though buyouts have existed since the 1980s. Increased efforts to develop a solid theoretical foundation would enhance our understanding of the role of buyouts in the economy, of the mechanisms behind externalities in a buyout, and the effects a buyout could have on static and dynamic efficiency. Further, a better developed formal framework would allow us to ask more general questions relating to the social welfare effects of buyouts. It would also be helpful in guiding future empirical work.

Second, future empirical studies should put more effort into determining the sources of changes in static and dynamic efficiency following a buyout. Studies such as Davis et al. (2009) are able to link the productivity improvements to closing less productive plants and opening new more productive ones and to increases in labor productivity following a buyout. But there may be other sources. For example, apart from reorganization of establishments, an internal reorganization of employees could have productivity enhancing effects, and improvements in management practices documented in Bloom et al. (2009) may also play an important role. 
Studies of buyouts using matched employer-employee datasets could shed some more light on these issues.

Third, more efforts in disentangling if real effects arise because of an ownership change or because of actions taken by private equity firms are needed. While it would to some extent be an apples-to-oranges comparison, disentangling the effects of an ownership change due to a merger from the effects of an ownership change due to a private equity buyout (in the spirit of Amess et al. (2008)) would be useful for understanding the possible effects of financial buyers on the real economy.

Fourth, future work should be dedicated to asking if the real effects differ across countries, and if so, why? Most empirical studies on real effects so far have been conducted on U.S. and U.K. transactions, yet there are indications that the real effects differ across countries. For example, evidence on employment suggests that buyouts in France have drastically different effects than buyouts in the U.S. and the U.K., indicating that country-specific factors could be important.

Finally, more work on how the real effects of buyouts change over time and with the type of buyout undertaken would be useful. The type of buyouts undertaken and the changes implemented by private equity firms after the buyout are likely to have changed over time as the industry has evolved and become more competitive. As argued by Holmström and Kaplan (2001), there were two reasons behind the takeover wave and the emergence of the buyout industry in the 1980s. First, deregulation coupled with new information and communication technologies introduced a gap between realized performance and potential performance that was maintained due to agency problems. Second, institutional investments in capital markets grew which facilitated the financing of takeovers aimed at improving performance. The combination of these two factors caused a wave of takeovers and the birth of buyouts. But as corporations improved governance and competition for targets increased, it is likely that private equity firms sought new ways of creating value and thriving in different institutional environments. While financial engineering (removing financial inefficiencies) and concentrating ownership to improve governance could have been the key drivers of their activities in the 1980s, the buyouts of today could be driven by other considerations more related to implementing better management practices and removing operational and strategic inefficiencies. Some types of buyouts could have stronger real effects than others. For example, Amess and Wright (2007) find different effects on employees depending on if a management buyout or a management buy-in took place, and Ughetto (2010) found ample evidence that the characteristics of the deal correlated with increases in patents after a buyout.

\section{Concluding Remarks}

This overview has argued that a buyout is likely to have real effects. By reducing agency problems, introducing uncertainty and temporary owners, and bringing in capital and knowledge, 
a buyout can cause changes in employment, productivity and long-run investments. Employment tend to marginally fall after a buyout in most countries studied, with the exception being France. There are clear evidence of productivity gains following a buyout, with part of these being shared with worker through higher wages. The evidence is mixed regarding effects on long-run investments. Thus, most of the concerns of industry critics seem unwarranted. Though job losses do occur following buyouts, there is no consistent evidence on reductions in long-run investments, and ample evidence that increases in productivity follow from a buyout. Through the real effects on the companies they acquire, private equity firms undertaking buyouts seem to be an important part of the industrial development process.

The results from academic studies are useful to keep in mind, in particular when evaluating policy proposals. Yet, more work is to be done on what role private equity firms fill in society as owners of assets. The real effects of private equity buyouts should prove a fruitful area for researchers for many years to come. 


\section{References}

[1] Achleitner, Ann-Kristin, and Oliver Klöckner. 2005. "Employment contribution of private equity and venture capital in Europe.” EVCA Research Paper.

[2] Amess, Kevin. 2002. "Management buyouts and firm-level productivity: evidence from a panel of UK manufacturing firms." Scottish Journal of Political Economy 49: 304-16.

[3] Amess, Kevin. 2003. "The effect of management buyouts on firm-level technical efficiency: evidence from a panel of UK machinery and equipment manufacturers.” Journal of Industrial Economics 51: 35-44.

[4] Amess, Kevin, Sara Brown, and Steve Thompson. 2007. "Management buyouts, supervision and employee discretion.” Scottish Journal of Political Economy 54: 447-74.

[5] Amess, Kevin, Sourafel Girma, and Mike Wright. 2008. "What are the wage and employment consequences of leveraged buyouts, private equity and acquisitions in the UK?" Nottingham University Business School Research Paper No. 2008/1.

[6] Amess, Kevin, and Mike Wright. 2007. "The wage and employment effects of leveraged buyouts in the UK." International Journal of the Economics of Business 14: 179-95.

[7] Andrade, Gregor, and Kaplan, Steven N. 1998. "How costly is financial (not economic) distress? Evidence from highly leveraged transactions that became distressed." Journal of Finance 53, 1443-93.

[8] Bergström, Clas, Mikael Grubb, and Sara Jonsson. 2007. "The operating impact of buyouts in Sweden: A study of value creation.” Journal of Private Equity 11: 22-39.

[9] Berle, Adolph, and Gardiner Means. 1932. The Modern Corporation and Private Property. New York: The Commerce Clearing House.

[10] Bernstein, Shai, Josh Lerner, Morten Sørensen, Per Strömberg. 2010. "Private Equity and Industry Performance.”, NBER Working Paper 15632.

[11] Bloom, Nick, Rafaella Sadun and John van Reenen. 2009." Do Private Equity-owned Firms have Better Management Practices?" In The Globalization of Alternative Investments Working Papers Volume 2: The Global Economic Impact of Private Equity Report 2009, ed. Anduradha Gurung and Josh Lerner, 25-43. Geneva: World Economic Forum.

[12] Boucly, Quentin, David Sraer, and David Thesmar. 2009. "Job creating LBOs.” Available at SSRN: http://ssrn.com/abstract=1354087 
[13] Bruining, Hans, Paul Boseli, Mike Wright, and Nicholas Bacon. 2005. "The impact of business ownership change on employee relations: buyouts in the U.K. and the Netherlands.” International Journal of Human Resource Management 16: 345-65.

[14] BVCA. 2006. "The economic impact of private equity in the UK." London: British Venture Capital Association.

[15] Cressy, Robert Clive, Munari, Federico and Malipiero, Alessandro, 2007. "Creative Destruction? UK Evidence that Buyouts Cut Jobs to Raise Returns." Available at SSRN: http://ssrn.com/abstract=1030830.

[16] Cumming, Douglas, Donald S. Siegel, and Mike Wright. 2007. "Private equity, leveraged buyouts and governance.” Journal of Corporate Finance 13: 439-60

[17] Cuny, Charles J. and Talmor, Eli, 2007. “A Theory of Private Equity Turnarounds.”, Journal of Corporate Finance 13: 629-646

[18] Davis, Steven, John Haltiwanger, Ron Jarmin, Josh Lerner, and Javier Miranda. 2008. "Private equity and employment." In The Globalization of Alternative Investments Working Papers Volume 1: The Global Economic Impact of Private Equity Report 2008, ed. Anduradha Gurung and Josh Lerner, 43-64. Geneva: World Economic Forum.

[19] Davis, Steven, John Haltiwanger, Ron Jarmin, Josh Lerner, and Javier Miranda. 2009. "Private equity, jobs and productivity." In The Globalization of Alternative Investments Working Papers Volume 2: The Global Economic Impact of Private Equity Report 2009, ed. Anduradha Gurung and Josh Lerner, 25-43. Geneva: World Economic Forum.

[20] Fidrmuc, Jana P., Roosenboom, Peter and Van Dijk, Dick J. C., 2008, "When Do Managers Seek Private Equity Backing in Public-to-Private Transactions?", EFA 2008 Athens Meetings Paper, Available at SSRN: http://ssrn.com/abstract=1101756

[21] Fox, Isaac, and Alfred Marcus. 1992. "The causes and consequences of leveraged management buyouts.” The Academy of Management Review 17: 62-85

[22] FSA. 2006. "Private equity: A discussion of risk and regulatory engagement." Financial Services Authority Discussion Paper DP06/6. London.

[23] Gertner, Robert, David S. Scharfstein and Jeremy C. Stein. 1994. "Internal versus external capital markets." Quarterly Journal of Economics 109: 1211-30.

[24] Gromb, Denis, and David S. Scharfstein. 2002. "Entrepreneurship in Equilibrium.” NBER Working Paper W9001. Cambridge, MA: National Bureau of Economic Research. 
[25] Grossman, Sanford, and Oliver Hart. 1982. "Corporate Financial Structure and Managerial Incentives." In The Economics of Information and Uncertainty, ed. John McCall, 107140. Chicago: University of Chicago Press.

[26] Hall, Bronwyn. 1990. "The impact of corporate restructuring on industrial research and development." Brookings Papers on Economic Activity 1: 85-136.

[27] Harris, Richard, Donald S. Siegel, and Mike Wright. 2005. "Assessing the impact of management buyouts on economic efficiency: plant level evidence from the United Kingdom." The Review of Economics and Statistics 87: 148-53.

[28] Hellmann, Thomas F. 2007. "When do employees become entrepreneurs?” Management Science 53: 919-33.

[29] Himmelberg, Charles P., and Bruce C. Petersen. 1994. "R\&D and internal finance: A panel study of small firms in high-tech industries." Review of Economics and Statistics 76: $38-51$.

[30] Holmström, Bengt. 1979. "Moral hazard and observability." The Bell Journal of Economics 10: 74-91.

[31] Holmström, Bengt and Steven Kaplan. 2001. "Corporate Governance and Merger Activity in the United States: Making Sense of the 1980s and 1990s." Journal of Economic Perspectives 15: 121-144.

[32] ITUC. 2007. "Where the house always wins: Private equity, hedge funds and the new casino capitalism.” Brussels: International Trade Union Confederation.

[33] Jensen, Michael. 1986. "Agency costs of free cash flow, corporate finance and takeovers." American Economic Review 76: 323-29.

[34] Jensen, Michael C. 1989. "The eclipse of the public corporation." Harvard Business Review 67: 61-74

[35] Jensen, Michael C., and William H. Meckling. 1976. "Theory of the firm: Managerial behavior, agency costs and ownership structure." Journal of Financial Economics 3: 30560

[36] Jensen, Michael C., and Kevin J. Murphy. 1990. "Performance pay and top management incentives." Journal of Political Economy 98:225-64.

[37] Kaplan, Steven N. 1989. "The Effects of Management Buyouts on Operating Performance and Value." Journal of Financial Economics 24: 217-54. 
[38] Kaplan, Steven N., Jeremy C. Stein. 1993. "The evolution of buyout pricing and financial structure in the 1980s." Quarterly Journal of Economics 108: 313-59.

[39] Kaplan, Steven N., and Per Strömberg. 2009. "Leveraged buyouts and private equity." Journal of Economic Perspectives 23, no. 1: 121-46.

[40] Lazear, Edward P. 2005. "Output-Based Pay: Incentives or Sorting?” In Accounting for Worker Well-being: Research in Labor Economics vol. 23, ed. Solomon W. Polachek, 1-25. Bingley: Emerald.

[41] Lichtenberg, Frank, and Donald S. Siegel. 1990. "The effects of leveraged buyouts on productivity and related aspects of firm behavior." Journal of Financial Economics 27: 165-94.

[42] Lerner, Josh, Sorensen, Morten and Strömberg, Per. 2008. "Private Equity and Long-Run Investment: The Case of Innovation". NBER Working Paper No. w14623. Available at SSRN: http://ssrn.com/abstract=1327245

[43] Long, William F., and David J. Ravenscraft. 1993. "LBOs, debt and R\&D intensity." Strategic Management Journal 14: 119-35.

[44] Lopez de Silanes, Florencio, Phalippou, Ludovic and Gottschalg, Oliver, 2009. "Giants at the Gate: Diseconomies of Scale in Private Equity." AFA 2010 Atlanta Meetings Paper. Available at SSRN: http://ssrn.com/abstract=1363883

[45] Murphy, Kevin J. 1985. "Corporate performance and managerial remuneration: An empirical analysis." Journal of Accounting and Economics 7: 11-42.

[46] Muscarella, Chris J., and Michael R. Vetsuypens. 1990. "Efficiency and organizational structure: A study of reverse LBOs." The Journal of Finance 45: 1389-413

[47] Myers, Stewart. 1977. “Determinants of Corporate Borrowing.” Journal of Financial Economics 5: 147-75

[48] Norbäck, Pehr-Johan, Persson, Lars and Joacim Tåg. 2010. "Buying to sell: A theory of buyouts." IFN Working Paper No. 817. Available at SSRN: http://ssrn.com/abstract=1532757

[49] Opler, Tim, 1992. "Operating Performance in Leveraged Buyouts: Evidence from 19851989." Financial Management 21: 27-34.

[50] Opler, Tim, and Titman, Sheridan, 1993. "The Determinants of Leveraged Buyout Activity: Free Cash Flow vs. Financial Distress Costs”, Journal of Finance 48:1985-1999. 
[51] Perotti, Enrico C and Spier, Kathryn E, 1993. "Capital Structure as a Bargaining Tool: The Role of Leverage in Contract Renegotiation," American Economic Review 83: 1131-41

[52] PSE 2007. "Hedge funds and private equity: A critical analysis." Report of the PSE Group in European Parliament. Brussels: Parti Socialiste Européen.

[53] Rajan, Raghuram and Luigi Zingales. 1995. "What Do We Know About Capital Structure? Some Evidence from International Data.” Journal of Finance 50: 1421-1460

[54] Shleifer, Andrei, and Lawrence H. Summers. 1988. "Breach of trust in hostile takeovers." In Corporate Takeovers: Causes and Consequences, ed. Alan J. Auerbach, 33-68. Chicago: University of Chicago Press, 1988.

[55] Shleifer, Andrei, and Robert W. Vishny. 1986. "Large shareholders and corporate control." Journal of Political Economy 94: 461-88

[56] Schaefer, Scott. 1998. "Influence Costs, Structural Inertia, and Organizational Change." Journal of Economics and Management Strategy 7: 237-263.

[57] Smith, Abbie J. 1990. "Capital ownership structure and performance: the case of management buyouts." Journal of Financial Economics 13: 143-65.

[58] Strömberg, Per. 2008. "The new demography of private equity." In The Globalization of Alternative Investments Working Papers Volume 1: The Global Economic Impact of Private Equity Report 2008, ed. Anduradha Gurung and Josh Lerner, 1-26. Geneva: World Economic Forum.

[59] Ughetto, Elisa, 2010. "Assessing the contribution to innovation of private equity investors: A study on European Buyouts.” Research Policy 39: 126-140

[60] Williamson, Oliver E. 1964. The economics of discretionary behavior: Managerial objectives in a theory of the firm. Englewood Cliffs, NJ: Prentice-Hall.

[61] Weir, Charlie, Jones, Pete and Wright, Mike, 2008. "Public to Private Transactions, Private Equity and Performance in the UK: An Empirical Analysis of the Impact of Going Private.” Available at SSRN: http://ssrn.com/abstract=1138616

[62] Wright, Mike, Hoskisson, Robert E., Busenitz, Lowell W. and Dial, Jay, 2001. "Finance and management buyouts: agency versus entrepreneurship perspectives." Venture Capital $3: 239-261$

[63] Wright, Mike, John Gilligan, and Kevin Amess. 2009. "The economic impact of private equity: what we know and what we would like to know." Venture Capital 11: 1-21 
[64] Wright, Mike, Steve Thompson, and Ken Robbie. 1992. "Venture capital and management-led leveraged buyouts: a European perspective.” Journal of Business Venturing 7: 47-71.

[65] Wright, Mike, Robert E. Hoskisson, Lowell W. Busenitz and Jay Dial, 2000. "Entrepreneurial Growth through Privatization: The Upside of Management Buyouts.” The Academy of Management Review 25: 591-601

[66] Zahra, Shaker A. 1995. "Corporate entrepreneurship and financial performance: The case of management leveraged buyouts.” Journal of Business Venturing 10: 225-47.

[67] Zwiebel, Jeffrey. 1996. "Dynamic capital structure under managerial entrenchment." American Economic Review 86:1197-215 


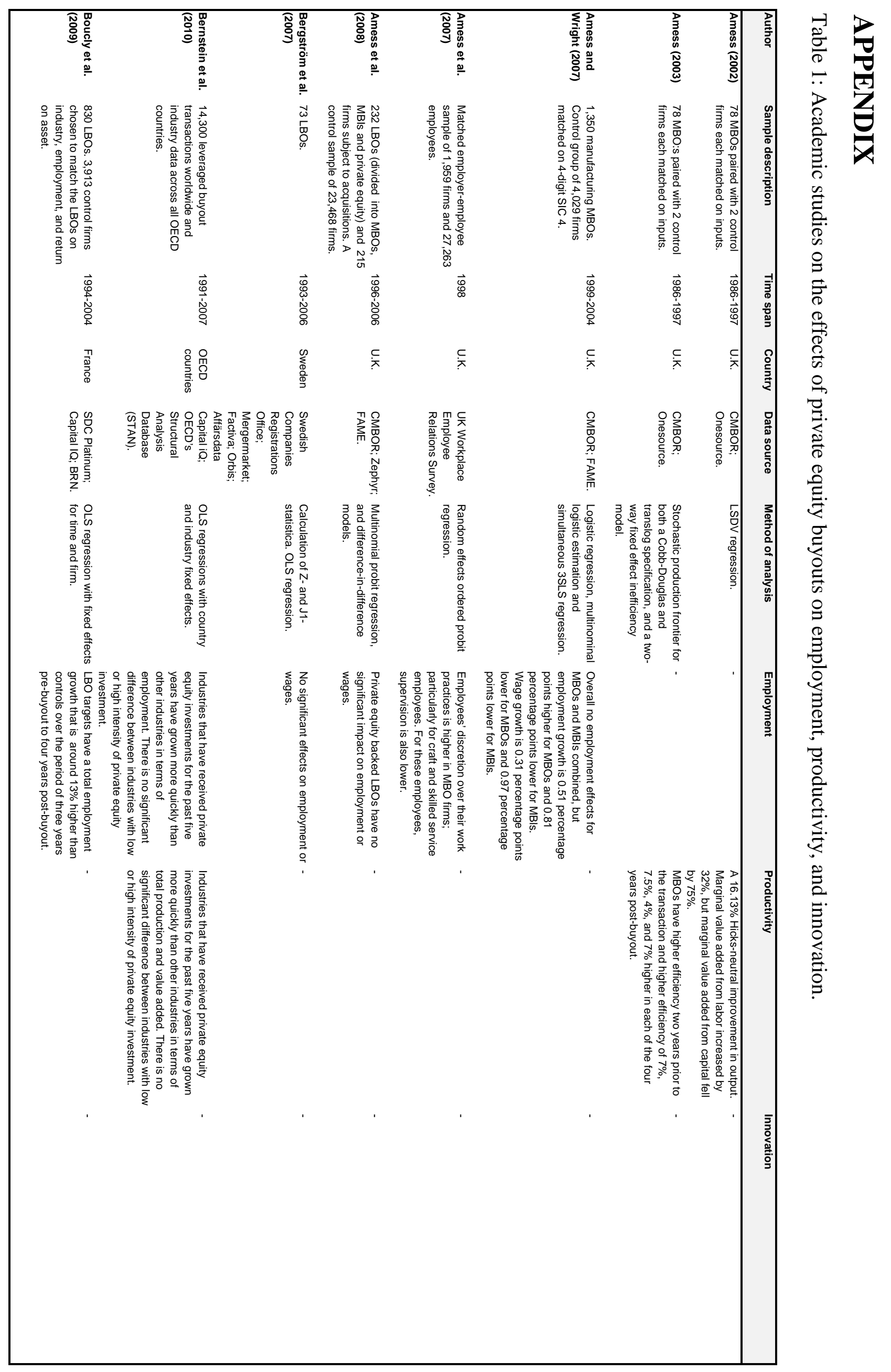




\begin{tabular}{|c|c|c|c|c|c|c|c|c|c|c|}
\hline 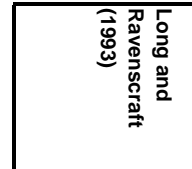 & 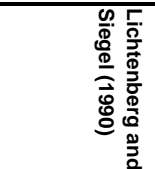 & 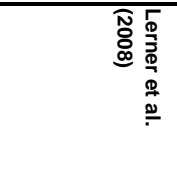 & 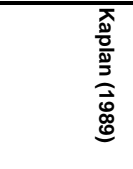 & 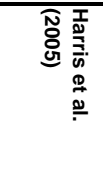 & 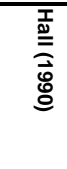 & 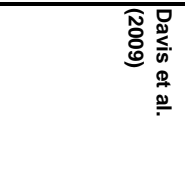 & 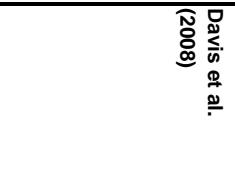 & 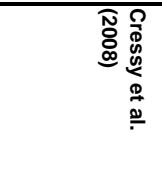 & 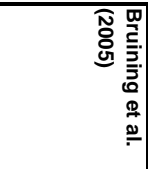 & 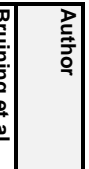 \\
\hline 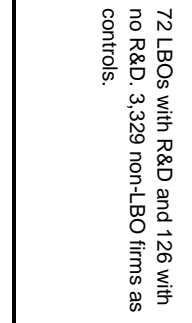 & 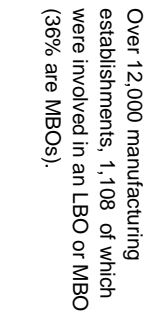 & $\begin{array}{l}\text { 离 } \\
\text { ज् } \\
\text { o } \\
0\end{array}$ & 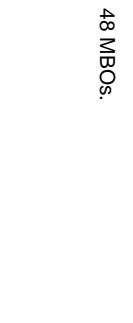 & 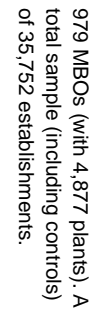 & 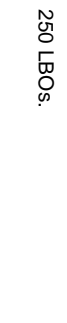 & 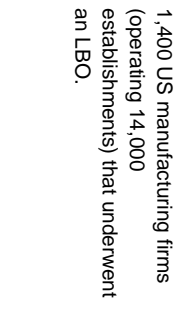 & 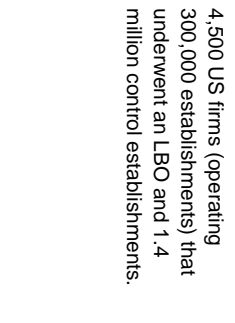 & 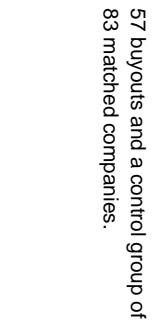 & 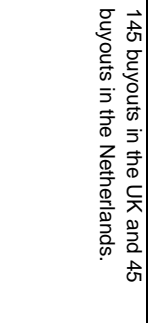 & |. \\
\hline $\begin{array}{l}\vec{\Phi} \\
\stackrel{\Phi}{\overrightarrow{\dot{\vec{\omega}}}} \\
\stackrel{\Phi}{v}\end{array}$ & 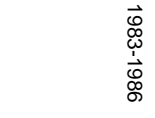 & 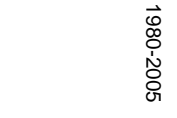 & 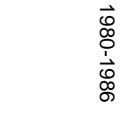 & 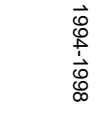 & 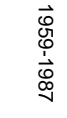 & 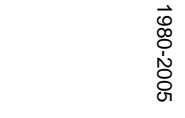 & 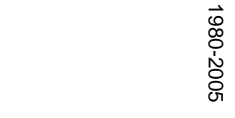 & 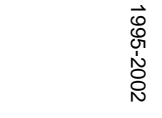 & $\begin{array}{l}\overrightarrow{0} \\
\stackrel{0}{\tau} \\
\overrightarrow{\vec{q}} \\
\infty\end{array}$ & 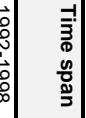 \\
\hline$\underset{c}{c}$ & $\underset{\infty}{\subset}$ & $\underset{c}{c}$ & c) & $\stackrel{\ulcorner}{\underset{x}{x}}$ & $\underset{c}{c}$ & cic & c్ & $\stackrel{\complement}{\grave{\lambda}}$ & 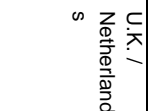 & 㝵 \\
\hline $\begin{array}{l}2 \\
0 \\
07 \\
0 \\
01 \\
0\end{array}$ & 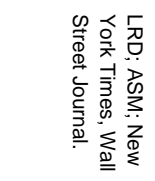 & 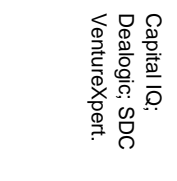 & 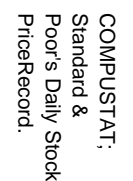 & 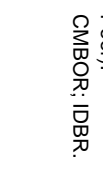 & 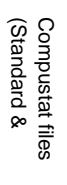 & 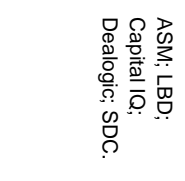 & 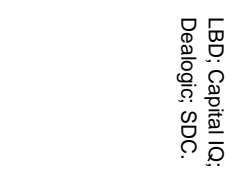 & 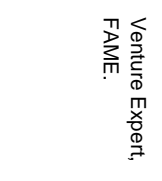 & 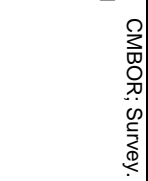 & 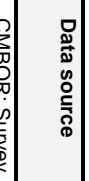 \\
\hline 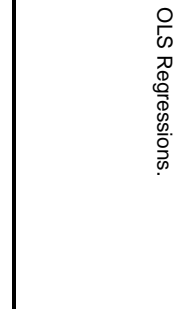 & 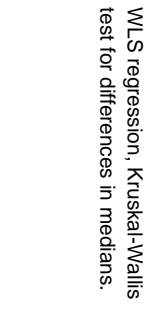 & 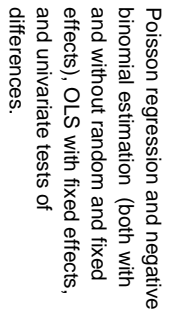 & 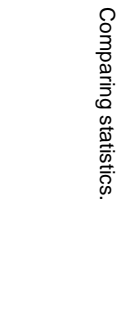 & 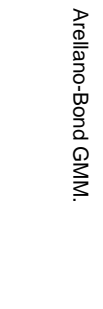 & 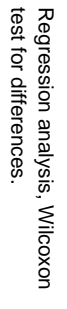 & 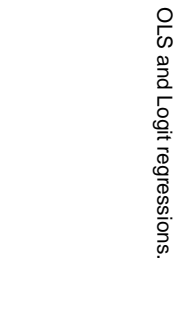 & 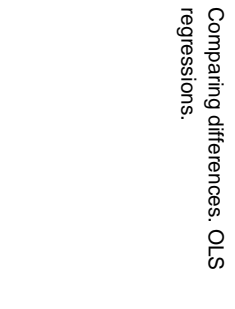 & 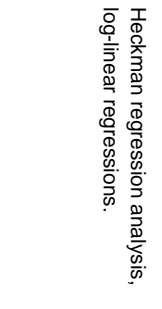 & 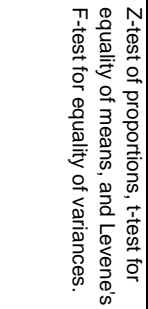 & 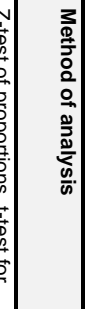 \\
\hline ' & 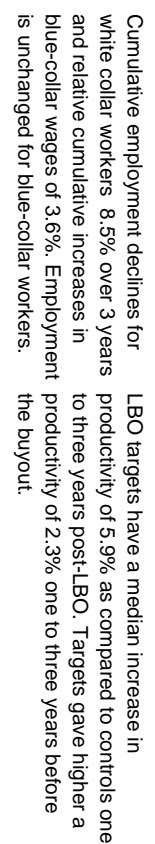 & ' & 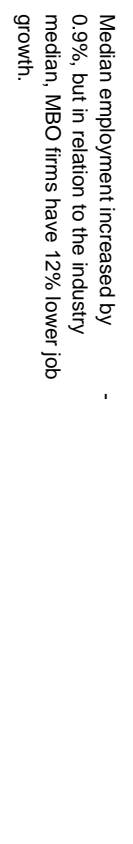 & 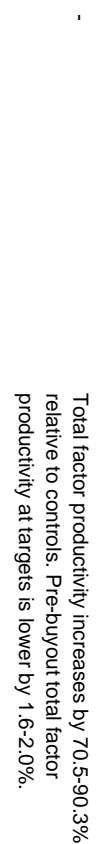 & & 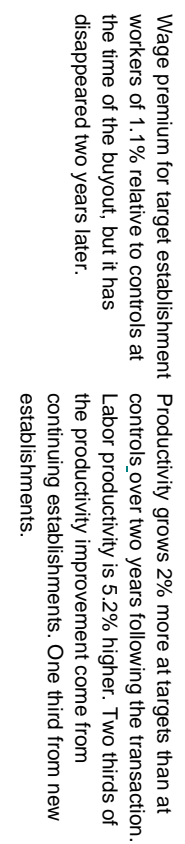 & 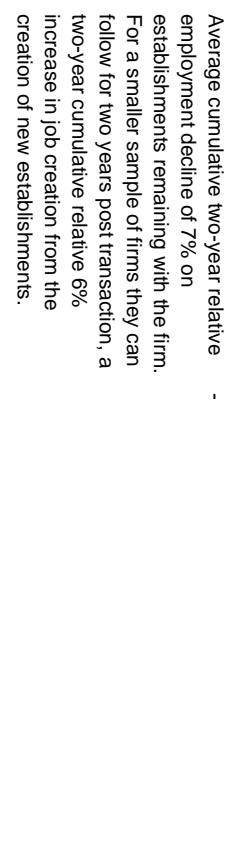 & 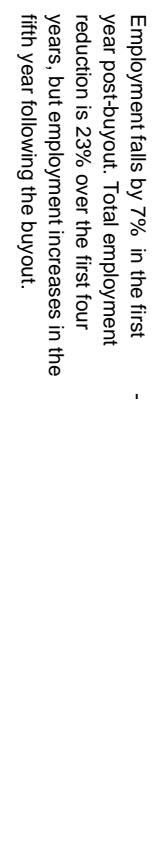 & 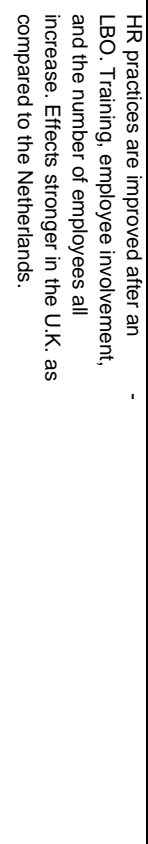 & 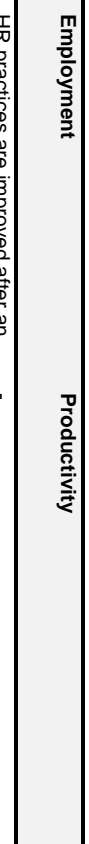 \\
\hline 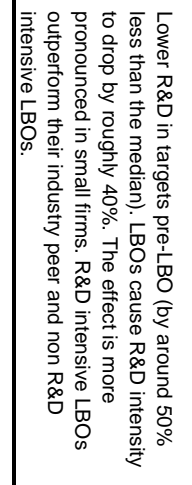 & 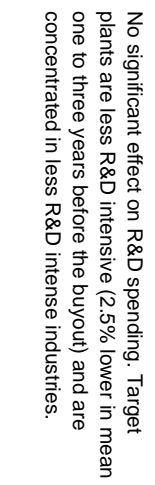 & 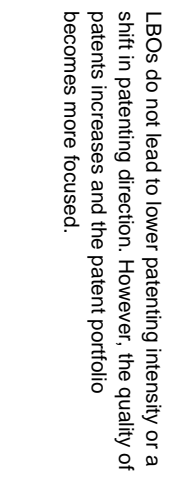 & & & 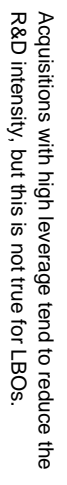 & & ' & & & 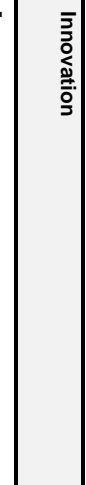 \\
\hline
\end{tabular}




\begin{tabular}{|c|c|c|c|c|c|c|c|}
\hline 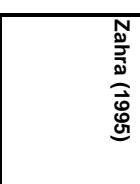 & 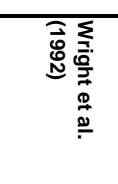 & 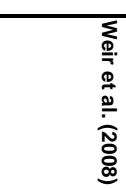 & 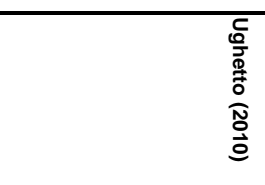 & 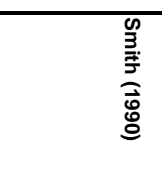 & 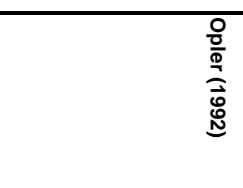 & 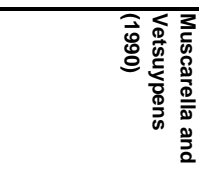 & 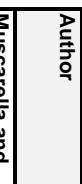 \\
\hline 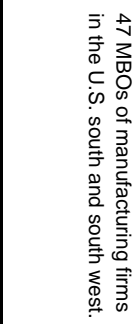 & $\begin{array}{l}\vec{\infty} \\
\stackrel{\infty}{\sim} \\
\stackrel{5}{\tilde{D}} \\
\stackrel{\infty}{\infty}\end{array}$ & 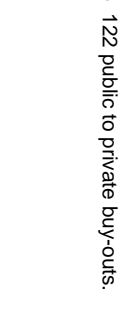 & 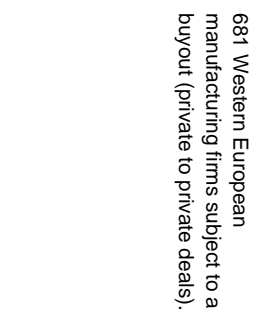 & 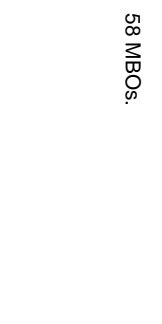 & 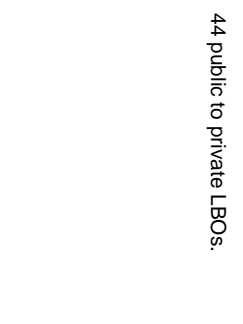 & 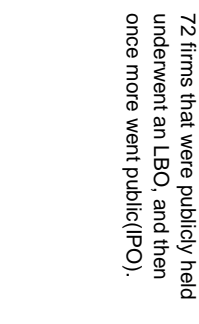 & \\
\hline$\vec{Ð}$ & 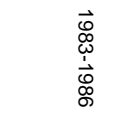 & $\begin{array}{l}\vec{\Xi} \\
\& \\
\stackrel{0}{0} \\
\stackrel{\phi}{\not}\end{array}$ & $\begin{array}{l}\overrightarrow{\$} \\
\$ \\
\mathbb{N} \\
\stackrel{+}{+}\end{array}$ & $\begin{array}{l}\overrightarrow{0} \\
\stackrel{\vec{v}}{\vec{\oplus}} \\
\stackrel{\Phi}{\circ}\end{array}$ & 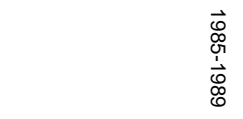 & 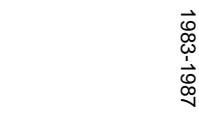 & |. \\
\hline c & $\underset{\lambda}{\complement}$ & $\underset{\lambda}{\stackrel{C}{X}}$ & 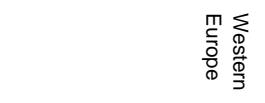 & $\underset{\infty}{C}$ & $\underset{i s}{c}$ & $\underset{c}{c}$ & \\
\hline 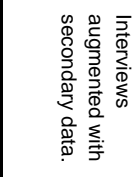 & 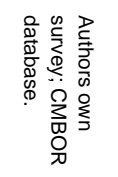 & 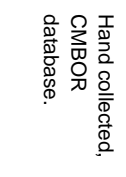 & 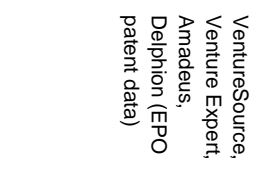 & 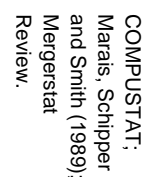 & 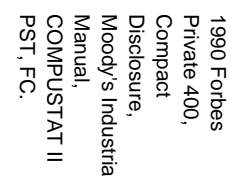 & 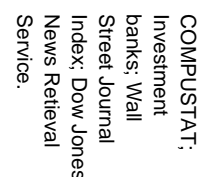 & 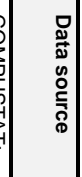 \\
\hline 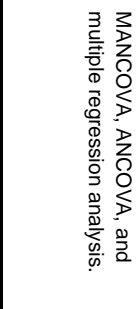 & 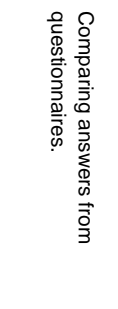 & 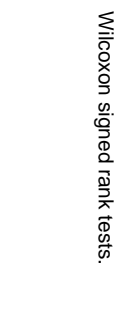 & 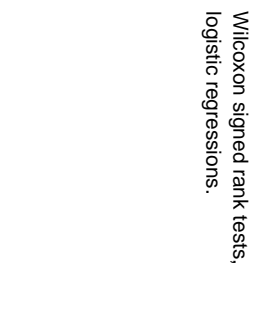 & 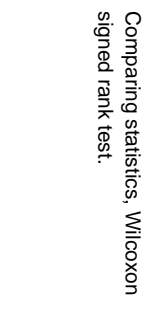 & 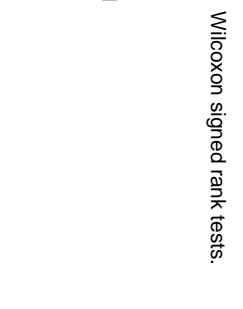 & 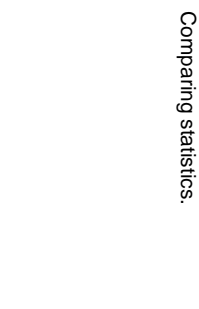 & 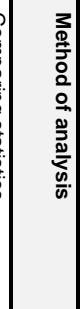 \\
\hline & 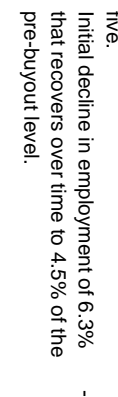 & 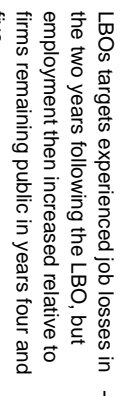 & & 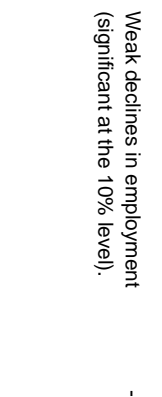 & 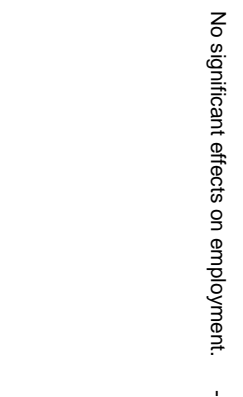 & 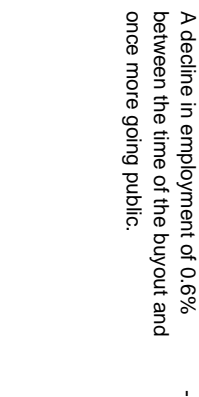 & 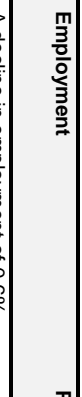 \\
\hline 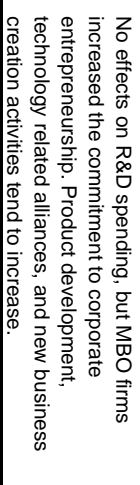 & 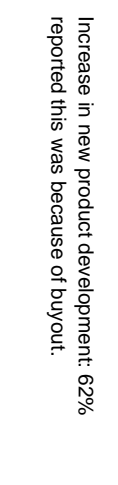 & ' & 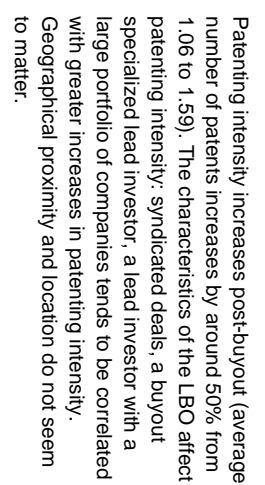 & 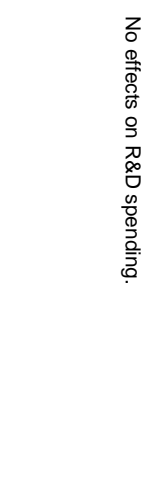 & 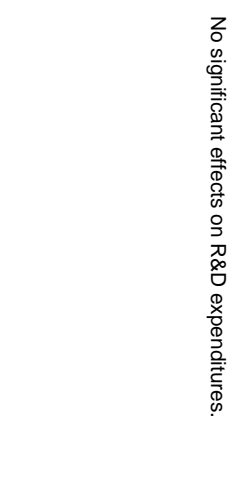 & & \\
\hline
\end{tabular}

